\title{
Water Sector Reforms, Commercialization and Financial Sustainability of Public Water Utilities in Kenya: The Case of Homa Bay Water and Sewerage Company Limited
}

\author{
Agwa Maryline Akinyi ${ }^{1} \&$ Paul A. Odundo ${ }^{2}$ \\ ${ }^{1}$ Department of Extra-Mural Studies, University of Nairobi, Kenya \\ ${ }^{2}$ Associate Professor, Department of Education Communication \& Technology, University of Nairobi, Kenya \\ Correspondence: Paul A. Odundo, Associate Professor, Department of Education Communication \& Technology, \\ University of Nairobi, Kenya. E-mail: odundopaul@yahoo.com
}

Received: October 23, 2017

doi:10.5539/ijbm.v13n7p179

\begin{abstract}
Reforms in the Kenyan water sector entrenched the aspect of commercialization, which subjected water services to market forces and necessitated establishment of autonomous public utilities, such as Homa Bay Water and Sewerage Company Limited, to improve cost recovery, efficiency and sustainability. This study focused on how commercialization, as an aspect of the reforms, influenced the utility's financial sustainability. A cross-sectional design, with mixed methods approach, guided the study. Primary data were sourced in mid 2017, from water officers, water users and water committee members. Quantitative techniques included cross-tabulation with Chi square statistic, Relative Importance Index and Kendall's Coefficient of Concordance. The results show that compliance of procurement activities to relevant legislations was the most important aspect influencing the utility's financial sustainability (relative weight $=0.838$ ); followed by effectiveness of internal audit in enforcing expenditure policies (relative weight $=0.825$ ); and relevance of activities on which water revenues were spent (relative weight $=0.812$ ). The analysis obtained a strong and significant concordance of respondents' views regarding relationship between financial management practices and the utility's financial sustainability (Kendall's $\mathrm{W}=0.862, \chi^{2}=64.491, \mathrm{df}=4 \& \rho$-value $\left.=0.000\right)$. Consequently, ensuring that procurement activities are strictly guided by procurement laws is important for preventing irregularities and minimizing loss of financial resources; while strengthening capacity of the internal audit department and enhancing its independence, are crucial antecedents for the utility's financial sustainability.
\end{abstract}

Keywords: Water sector, reforms, commercialization, financial sustainability, water utilities

\section{Introduction}

The Kenyan water sector has undergone tremendous reforms since the first National Policy on Water Resources Management and Development was formulated in 1999, and the Water Act enacted in 2002. The reforms focused on improving: supply of good quality water in sufficient quantities, safe disposal of waste water, efficiency in service delivery, sustainability of water services, conservation and protection of water resources, as well as allocation of such resources in a sustainable, rational and economical manner. The reforms also aimed at establishing an efficient and effective institutional framework to manage and develop the sector, as well as developing a sustainable financing system to finance the development of pro-poor water and sewerage initiatives (Water Resources Management Authority [WRMA], 2013; Rampa, 2011; World Bank, 2008).

Key features of the national water policy included a call for decentralization of operations from the central government to other actors, including local authorities and the private sector; increased involvement of communities to improve efficiency and sustainability in service delivery; as well as the need to amend the existing Water Act Cap 372 to enhance its relevance in supporting sector reforms (Obosi, 2011). On its part, the Water Act, 2002 provided a crucial legal foundation for water sector reforms, including managing water resources, eliminating government's participation in direct delivery of services, providing a mechanism for financing water initiatives as well as strengthening the institutional framework (Obosi, 2011; Rampa, 2011; World Bank, 2008). In this regard, the Water Act, 2002 created a number of institutions, as indicated in Figure 1, to enhance protection and management of water resources, as well as delivery of water and sewerage services. 


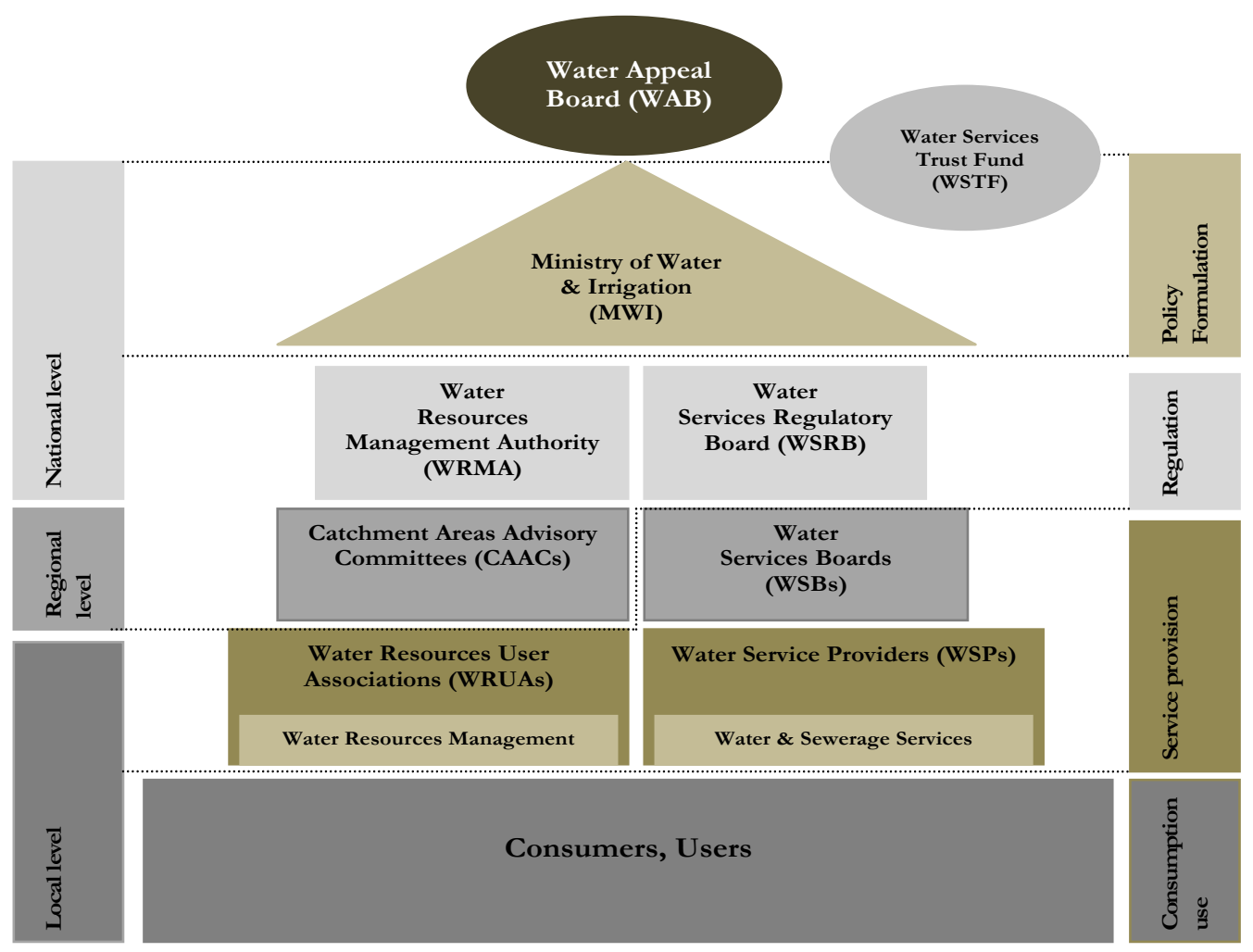

Figure 1. The institutional framework created by the Water Act, 2002

Source: Rampa, 2011.

At the national level, the Act established Water Appeal Board (WAB) to adjudicate on disputes; Water Services Trust Fund (WSTF) to finance pro-poor investments; Water Resources Management Authority (WRMA) to manage and protect Kenya's resources; as well as Water Services Regulatory Board (WASRB) to set standards and regulate the water sector. At the regional level, the Act created Catchment Area Advisory Committees (CAACs) to support the WRMA's obligations; and Water Service Boards (WSBs) to develop assets, contract and manage service providers, as well as ensure efficient and economical provision of water and sewerage services. Homa Bay County is under the jurisdiction of Lake Victoria South Water Services Board (LVSWSB). At the local level, Water Resource User Associations (WRUAs) were established as a medium for cooperative management of water resources and conflict resolution. Also established at the local level were Water Service Providers (WSPs) who are agents authorized by a WSB through Service Provision Agreements to provide water and sewerage services, as well as develop, rehabilitate and maintain water and sewerage facilities on behalf of WSBs. According to the Act, WSPs include public and private companies, public enterprises/corporations, non-governmental organizations, individuals and community-based organizations providing water and sewerage services in accordance with contractual agreement with a WSB (Obosi, 2011; Norman \& Parker, 2011; Rampa, 2011; World Bank, 2008; Government of Kenya, 2002).

Water sector reforms brought to the fore the aspect of commercialization of water services, which basically means the introduction of business principles and management practices in the public sector to improve cost recovery, as well as enhance efficiency and sustainability of public services (K'Akumu, 2006). In the water sector, commercialization entailed incorporation of autonomous water and sewerage public limited companies, hereafter referred to as public water utilities, by local government authorities to overcome the challenges of poor billing and revenue collection practices, high levels of unaccounted for water, high default rates and low cost recovery (K'Akumu, 2006). One such public water utility was the then South Nyanza Water and Sewerage Company (SNWSC), which was incorporated in 2007 to provide water and sewerage services in the then, Rachuonyo, Homa Bay and Suba Districts. When county governments were established in 2013, SNWSC was taken over by the County Government of Homa Bay and rebranded as Homa Bay Water and Sewerage Company Limited (HOMAWASCO).

An overriding purpose of commercialization of water services was to improve financial management practices, 
towards achievement of financial sustainability of public water utilities. Financial sustainability enables organizations to: maintain general operations, ensure continuous delivery of services and invest in infrastructure. Besides, organizations that are financially sustainable have better chances of seizing opportunities and reacting to unexpected challenges without depending on external funding sources (Williams, 2013; McPhail, Locussol, \& Perry, 2012; Bowman, 2011). More specifically, a water utility is considered to be financially sustainable when it's able to off-set operational and maintenance (O\&M) costs as well as finance the development of infrastructural facilities (Williams, 2013; McPhail et al., 2012).

Extant literature reveals that financial sustainability of public water utilities is a function of multiple factors, including financial management practices such as compliance with relevant regulations when procuring goods, services and works (Adank \& Tuffuor, 2013); effectiveness of internal control mechanisms in enforcing adherence to expenditure policies (Nankunda, 2013); as well as relevance of activities on which water revenues are spent (Mimrose \& Gunawardena, 2011; Wambua, 2004). Other aspects of financial management that influence financial sustainability of public water utilities include efficiency of revenue collection and ability to meet revenue targets, effectiveness of external audit in propagating ideal financial management practices as well as the degree of fiscal discipline, which manifests through the frequency of budget overruns (Adank \& Tuffuor, 2013; Mimrose \& Gunawardena, 2011; Whittington, Davis, Prokopy, Komives, Thorsten, Lukacs, \& Wakeman, 2009).

In Kenya, available literature dwells on the general performance of public limited water utilities, with very few focusing on the relationship between financial practices and financial sustainability of public water utilities. For instance, water sector review reports associate public water utilities with improved revenue collection efficiency, a reliable stream of finances, as well as a reduction in the amount of water lost through burst pipes, leakages and pilferage (UNICEF \& WHO, 2015; WASRB, 2013; World Bank, 2012). The reports also identify issues that remain key impediments to performance, including low coverage of rural communities, poor corporate governance practices, diversion of water revenues, high levels of unaccounted for water, weak financial management practices and low O\&M cost recovery, among other challenges (UNICEF \& WHO, 2015; WASRB, 2013; World Bank, 2012).

Just two years into the reforms triggered by the Water Act, 2002, Wambua (2004) conducted case studies of three public water utilities, namely, Nyeri Water and Sewerage Company Limited, Eldoret Water and Sewerage Company Limited and Nairobi Water and Sewerage Company Limited. The study revealed several challenges that affected financial sustainability of the utilities; including weak internal control for mechanisms for managing expenditure, weak internal audit departments, delays in external auditing, inconsistent implementation of audit recommendations, ineffective revenue collection mechanisms, diversion of water revenues to irrelevant expenditures, non-compliance with procurement regulations, as well as frequent budget overruns, among others. As a result, none of the three public water utilities had achieved financial sustainability (Wambua, 2004). Even though the theme of Wambua's study is relevant to that of this study, a few fundamental differences are notable in terms of geographical setting, timing, methodological approaches and investigative intensity. The purpose of this study was determine how commercialization, as an aspect of the reforms, influenced the financial sustainability of HOMAWASCO, with a view to informing stakeholders, contributing policy discourses and programming decisions, as well as stimulating relevant research to aid sector development in Kenya and other developing countries. In this regard, commercialization was operationalized in terms of financial management practices, while financial sustainability was measured in terms of the utility's perfromance in defraying O\&M costs.

\section{Literature Review}

Traditionally, water services have been provided by public agencies, including government ministries, departments, state corporations and local government authorities, because water is a basic need, a service of public interest and a fundamental element of human rights (K'Akumu, 2006). However, in many developing countries, delivery of water services by public agencies has experienced challenges such as poor billing and revenue collection practices, low revenues, high level of unaccounted for water, high unit price of water, high default rates, low cost recovery, poor financial management practices, as well as unaccountable management systems, which have been linked to lack of commercial orientation in service delivery (Gia \& Fugelsnes, 2010; Whittington et al., 2009; K'Akumu, 2006). In response to these challenges, a new paradigm that aimed at subjecting water services to market forces of demand and supply emerged between 1990 and 2005. The new paradigm sought to enhance efficiency and sustainability of water services by increasing private sector participation, while reducing the role of government in direct delivery of water services (United Nations, 2011; K'Akumu, 2006). 
In Kenya, water sector reforms began in earnest in 2002 with enactment of the Water Act, whose key hallmarks include separation of policy formulation, regulation and service provision; as well as definition of clear roles for all stakeholders within the decentralized institutional framework (Obosi, 2011; Norman \& Parker, 2011; World Bank, 2008). Besides, the Act created a water market where WSPs are contracted by WSBs and licensed to provide competitive services on specific terms (World Bank, 2008; Government of Kenya, 2002). By subjecting water services to market forces, the reforms entrenched the aspect of commercialization of water services, which entailed operation of water utilities on business principles to achieve efficiency, profitability and financial sustainability (K'Akumu \& Appida, 2006). As noted by Sanders and Fitts (2011), financial sustainability implies the ability of water utilities to defray O\&M costs consistently, and to maintain an acceptable level of services over time; while Adams (2012) observes that a water utility is financially sustainable if the management is able to recover full costs for O\&M as well as retain sufficient revenues for capital investments. Regardless of whether an organization is public or private, profit or non-profit, achieving financial sustainability is central to its functionality and survival.

Castro, Msuya and Makoye (2009) differentiate the two concepts of 'operational' and 'maintenance' costs. In this regard, operational costs include costs arising from daily management of water utilities, including pump operation, water treatment, rationing, network surveying, recording and reporting. Maintenance costs include costs emanating from technical aspects such as availability of spare parts and technical skills, replacement of worn-out parts, as well as administrative and managerial actions that keep water supply systems running. Furthermore, Castro et al. (2009) identifies three different types of maintenance activities, with varying degree of cost implications, including preventive, corrective and rehabilitative. Whereas preventive maintenance is planned and executed regularly to keep water infrastructure in good working condition; corrective maintenance involves activities responding to breakdowns or infrastructure deterioration, while rehabilitative maintenance involves repair of major defects to restore water supply. Key indicators of financial sustainability associated with maintenance of water utilities include the consistency of preventive maintenance, duration between occurrence of breakdowns and onset of corrective maintenance, as well as interludes between any two successive rehabilitative sessions (McPhail et al., 2012; Castro et al., 2009). In this study, financial sustainability was measured in terms of HOMWASCO's perfromance in defraying O\&M costs, over the preceding one-year period.

The most common and widely applied theoretical model of sustainable delivery of social services is one that was developed by the World Bank in 1990, focusing on technical, institutional, social, environmental and financial aspects (World Bank, 1997). Based on the World Bank's model, development practitioners have come up with better models to deepen and widen understanding of project sustainability in various sectors and contexts. One such initiative culminated to the Four Pillars Model of Financial Sustainability, which was developed in 2001 by Nature Conservancy, in collaboration with the United States Agency for International Development. The model's purpose was to enable all development organizations strengthen their capacity to achieve financial sustainability and deliver lasting services without depending on external funding sources (McPhail et al., 2012; Leon, 2001). The model posits that financial sustainability is a value that all organizations, be they profit or non-profit, strive to achieve, in order to fulfill their purpose in society (McPhail et al., 2012; Leon, 2001).

According to the model, achievement of financial sustainability requires organizations to develop four fundamental pillars, including strategic and financial planning, income diversification, sound administration and financial management, as well as own income generation (McPhail et al., 2012; Leon, 2001). Sound administration and financial management pillar requires organizations to have in place proper administrative and financial management systems to oversee revenue generation and expenditure of financial resources (Leon, 2001). In Kenya, the water sector reforms brought to the fore the aspects of commercialization of water services, which entailed orienting water utilities towards cost recovery, efficiency and financial sustainability (K'Akumu \& Appida, 2006). Commercialization of water services requires utilities to entrench sound administrative and financial management practices targeting accounting systems, internal and external audit, procurement, expenditure of water revenues, and budgeting, among other aspects, in order to achieve financial sustainability. In the case of HOMAWASCO, little is documented regarding the extent to which water sector reforms, through commercialization of services, have improved financial management practices; as well as the influence of such financial management practices on the utility's financial sustainability. The four pillars model provided the theoretical basis for the study.

Extant literature shows that financial management practices are important antecedents to organizational financial sustainability. Within the context of water utilities, relationship between the two concepts has been examined by Adank and Tuffuor (2013), Nankunda (2013), Mimrose and Gunawardena (2011), Norman and Parker (2011), Fragano (2010), Whittington et al., (2009), as well as Wambua (2004), just to cite a few. An overriding finding of 
the studies is that the ability of water utilities to achieve financial sustainability is influenced by various financial management practices, including type of accounting systems adopted, consistency of utilities in achieving revenue targets, relevance of activities on which revenues are spent, consistency of expenditure with approved budgets, compliance of procurement activities with relevant regulations, effectiveness of internal audit in enforcing expenditure policies, as well as effectiveness of external audit in improving financial management practices.

For instance, in Ghana, Adank and Tuffuor (2013) found a significant relationship between financial sustainability of water utilities and auditing of financial statements, disclosure of financial reports, implementation of actions recommended by such reports, as well as efficiency of procurement procedures. In Paraguay, Fragano (2010) attributed the success of peri-urban water schemes to the introduction of computerized accounting systems, which improved efficiency in management of cash flows, budgets, procurement activities, as well as expenditure of water revenues. In Kenya, Norman and Parker (2011) found that the introduction of electronic payment methods using mobile phones improved revenue collection efficiency, achievement of revenue targets and the ability of rural water utilities to meet O\&M costs. Still in Kenya, Wambua (2004) reported that improper use of water revenues is one of the factors that impeded financial sustainability of three public water utilities.

The study applied the conceptual framework indicated in Figure 2, which was founded on the Four Pillars of Financial Sustainability Model. The framework shows the hypothesized relationship between each pillar and financial sustainability of water utilities. Each pillar was operationalized in terms of measurable indicators, which were designated as independent variables.

\section{INDEPENDENT VARIABLES}

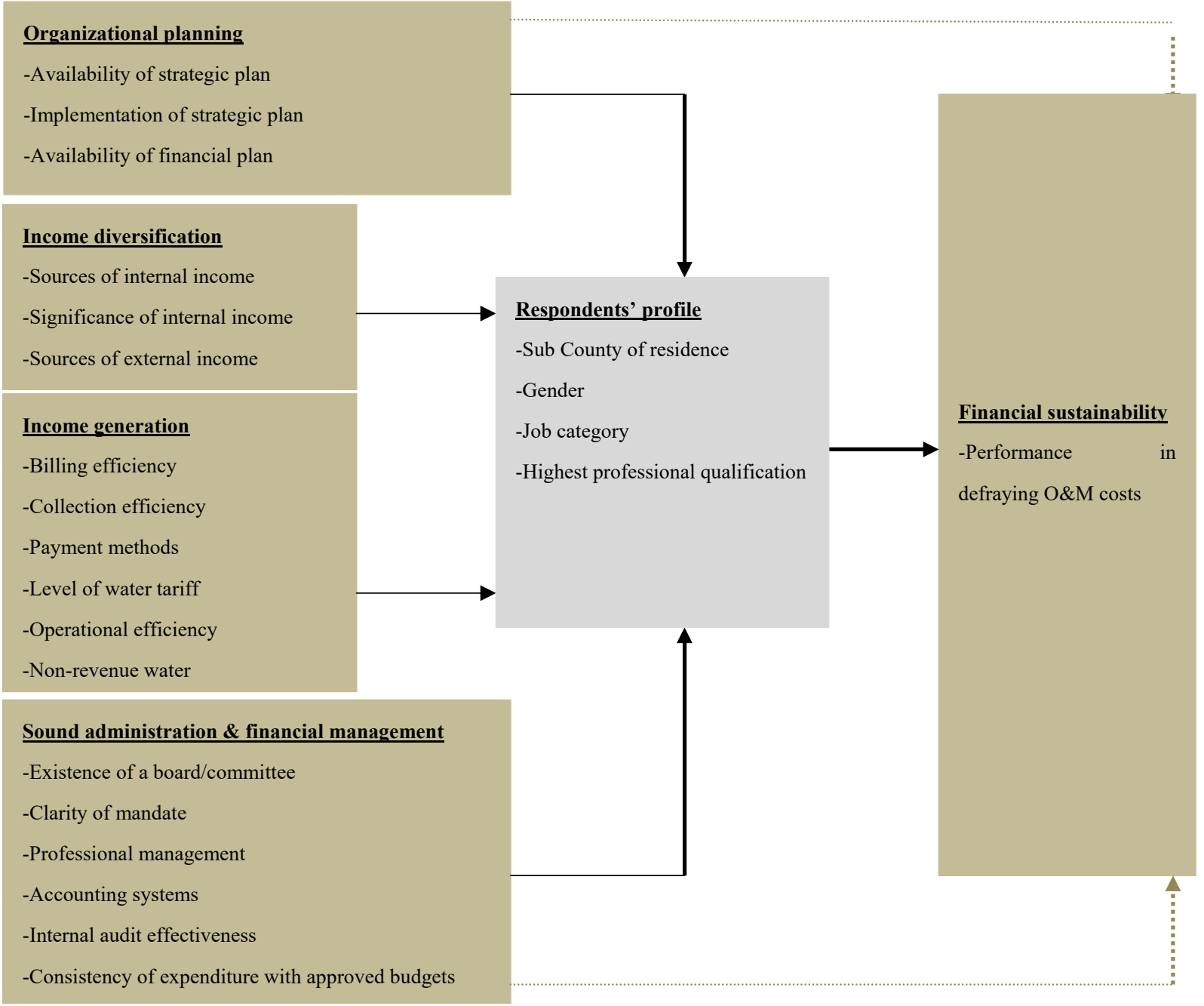

Figure 2. Conceptual framework showing hypothesized relationship between key concepts 
This article focuses on the influence of sound administration and financial management pillar on the financial sustainability of HOMAWASCO. The pillar was operationalized in terms of five indicators, hereafter referred to as financial management practices, including compliance of procurement activities to relevant legislations, effectiveness of internal audit in enforcing expenditure policies, effectiveness of external audit in improving financial management practices, relevance of activities on which water revenues are spent, as well as conformance of expenditure to approved budgets.

\section{Methodology}

The study design was informed by two philosophical approaches of social science research, including positivism and constructivism. The positivist school of thought holds that information derived objectively from sensory experience with phenomena is the exclusive source of all authoritative knowledge, provided that the phenomenon in question and the researcher are mutually independent. Positivist scholars focus on determining causal relationships between sets of phenomena by testing null hypotheses. On the other hand, the constructivist school of thought believe that phenomena are socially constructed and are subjectively observed, which implies that constructivist researchers are part of the phenomenon being observed. A constructivist researcher focuses on the meaning of phenomena observed, examines its totality and induces generalizations (Wong, 2014; Ashley \& Orenstein, 2005; Easterby-Smith, Thorpe, \& Lowe, 1991).

The study was designed to capture cross-sectional data to enable the investigator determine bivariate and causal relationships between financial management practices and financial sustainability of HOMAWASCO, in accordance with the tenets of positivism. The study was also designed to source qualitative data using Key Informant Interviews (KIIs) and Focused Group Discussions (FGDs), in accordance with the constructivist school of thought. The information was used to examine the totality of relationship between financial management practices and the utility's financial sustainability. Based on the positivist and constructivist thoughts, the investigator applied a mixed methods approach; where quantitative methods elicited information for descriptive and inferential purposes, while qualitative methods obtained detailed case analysis information for validating quantitative results (Sale, Lohfeld, \& Brazil, 2002; Hughes \& Sharrock, 1997).

The study targeted six rural water schemes, managed by HOMAWASCO. Within the schemes, the study targeted water officers, who were grouped into five job categories, including managerial, operations, technical, commercial and finance. The study also targeted three groups of water users, including commercial, government and domestic. Commercial users included restaurants and guest houses, fish processors, launders, and car washers. Government institutions included health facilities, ministries and academic institutions; while domestic users include household heads. In addition, the study targeted scheme management committee members. The quantitative approach targeted water officers in five job categories, whose distribution is indicated in Table 1.

Table 1. Distribution of the populations and sample sizes for various categories of water officers

\begin{tabular}{lllll}
\hline Job category & Specific cadre & Population $\left(\mathbf{N}_{\mathbf{i}}\right)$ & Sample $\left.\mathbf{( n}_{\mathbf{i}}\right)$ & Sampling method \\
\hline \multirow{2}{*}{ Managerial } & CEO + Departmental heads & 5 & 5 & Census \\
& Scheme managers & 6 & 6 &, \\
Operations & Coordinators & 12 & 12 & $"$ \\
& Station in-charges & 24 & 24 & $”$ \\
Technical & Water engineers/technicians & 108 & 67 & Fisher's formula \\
Commercial & Commercial officers & 150 & 86 &, \\
Finance & Finance officers & 10 & 10 & Census \\
Total & & $\mathbf{3 1 5}$ & $\mathbf{2 1 0}$ & \\
\hline
\end{tabular}

Fisher's formula for sample size determination from finite populations states that: $n_{i}=\left\{\frac{\delta(1-\delta)}{\left[\left(\frac{\alpha}{Z}\right)^{2}+\delta(1-\delta) / N_{i}\right]}\right\} * \mu_{i}$

Where: $\mathrm{n}_{\mathrm{i}}=$ sample size, $\mathrm{N}_{\mathrm{i}}=$ population, $\delta=$ estimated population variance: $0.5, \alpha=$ desired precision: $0.05, \mathrm{Z}=$ confidence level: 1.96 for $95 \%$ on the normal distribution curve and $\mu_{i}=$ design effect, default: 0.6 (Fink, 1995). Taking the example of commercial officers, whose population was 150 , the computation obtains a sample size of 86 respondents. In addition, qualitative data were obtained through 12 KIIs and 6 FGDs.

Primary data were sourced between March and May 2017. A standard self-reporting survey questionnaire was applied to source quantitative data from water officers. The instrument was pre-tested in two water schemes in Siaya County, under the management of Siaya-Bondo Water and Sewerage Company Limited (SIBOWASCO). 
The pre-test covered 22 water officers, about $10 \%$ of the sample size, which according to Sheatsley (1983), is sufficient to discover flaws in data collection instruments. Content Validity Index (CVI) was computed for the survey questionnaire, and the process obtained a CVI of $64.7 \%$, which suggests that content validity was good, according to Polit and Beck (2006). Reliability of data collection questionnaire was determined by computing Spearman-Brown Prophecy Coefficient. The process obtained a Coefficient of 0.83, which according to Garson (2009), suggested a 'good' level of reliability.

Both quantitative and qualitative techniques were applied to process and analyze data. Quantitative techniques included cross-tabulation with Chi square statistic $\left(\chi^{2}\right)$ to determine the statistical association between financial management practices and the utility's financial sustainability. Relative Importance Index (RII) was also applied to determine the relative importance of each financial management practice in relation to the utility's financial sustainability. Kendall's Coefficient of Concordance (W) was also applied to determine the extent to which respondents' views regarding the influence of financial management practices on the utility's financial sustainability converged. All quantitative analyses were performed using the Statistical Package for Social Sciences (SPSS) and Microsoft Excel. In addition, qualitative data were transcribed and analysed using Nvivo 10 to identify emerging themes and patterns.

Regarding ethical considerations, the investigator sought informed consent from potential respondents; and the process involved briefing them about the study, voluntary participation, withdrawal of consent and confidentiality of information sourced. Ethical clearance was obtained from the University of Nairobi Ethics and Research Committee; a research permit was obtained from the National Commission for Science, Technology, and Innovation, while introduction letters were obtained from the University of Nairobi and Ministry of Water Services and Environment, Homa Bay County.

\section{Results}

In this study, respondents were required to indicate their honest views regarding the utility's performance in defraying O\&M costs on a four-point measurement scale, calibrated as 'very good', 'good', 'poor' and 'very poor'. The results show that of the 210 water officers who responded by filling self-reporting questionnaires, 45 $(21.4 \%)$ rated the utility's performance as 'very good', while $52(24.8 \%)$ described it as 'good'. Those who felt that the performance was 'poor' were 87 (41.4\%), while $26(12.4 \%)$ rated it as 'very poor'. For the convenience of data analysis, 'very good' and 'good' performances were collapsed into one category designated as 'GOOD', while 'poor' and 'very poor' performances were lumped into the category designated as 'POOR'. Based on this, cumulative results show that up to $94(44.8 \%)$ respondents described the utility's performance as GOOD, while $116(55.2 \%)$ indicated views which suggested it performed 'POORLY' in defraying O\&M costs. The results presented in the following sub-sections are organized into four themes, including bivariate analysis of respondents' attributes and the utility's financial sustainability; bivariate analysis of financial management practices and the utility's financial sustainability; relative importance analysis of financial management practices, as well as concordance of respondents' views regarding the influence of financial management practices on the utility's financial sustainability.

\subsection{Bivariate Analysis of Respondents'Attributes and the Utility's Financial Sustainability}

The questionnaire required water officers to indicate background attributes, including Sub County of residence, water scheme, job category, gender and highest professional qualification. The attributes were cross-tabulated against views regarding the utility's performance in defraying O\&M costs. The results in Table 2 show that of the 210 respondents, 84 (40.0\%) were residents of Homa Bay Town Sub County, 62 (29.5\%) were natives of Rachuonyo North, 47 (22.4\%) lived in Rachuonyo South, while 17 (8.1\%) resided in Mbita Sub County. Regarding views on the utility's performance in defraying O\&M costs, Table 3 shows that of the 94 respondents who felt that the utility's performance was GOOD, 46 (48.9\%) were natives of Rachuonyo South, while 23 (24.5\%) resided in Homa Bay Town. Contrastingly, among those who rated performance as POOR (116), 39 (33.6\%) were residents of Homa Bay Town, while 38 (32.8\%) dwelt in Rachuonyo South. The analysis obtained a computed Chi square $\left(\chi^{2}\right)$ value of 5.753, with 3 degrees of freedom (df) and a $\rho$-value of 0.124 , which suggests lack of a significant association between Sub Counties of residence and views regarding the utility's performance in defraying O\&M costs. The results imply that views regarding the utility's performance did not vary significantly across the four Sub Counties covered by the study. 
Table 2. Cross-tabulation of respondents' profile and the utility's financial sustainability

\begin{tabular}{|c|c|c|c|c|c|c|c|c|c|}
\hline \multirow[b]{3}{*}{ Attributes } & \multicolumn{6}{|c|}{ The utility's performance in defraying O\&M costs } & \multirow{2}{*}{\multicolumn{3}{|c|}{$\begin{array}{l}\text { Summary of Chi Square } \\
\text { Results }\end{array}$}} \\
\hline & \multicolumn{2}{|l|}{ GOOD } & \multicolumn{2}{|l|}{ POOR } & \multicolumn{2}{|l|}{ TOTAL } & & & \\
\hline & Count & Percent & Count & Percent & Count & Percent & $\chi^{2}$ & $d f$ & $\rho$-value \\
\hline \multicolumn{10}{|c|}{ Sub County of residence } \\
\hline Homa Bay Town & 23 & 24.5 & 39 & 33.6 & 62 & 29.5 & & & \\
\hline Rachuonyo North & 18 & 19.1 & 29 & 25.0 & 47 & 22.4 & 5.753 & 3 & 0.124 \\
\hline Rachuonyo South & 46 & 48.9 & 38 & 32.8 & 84 & 40.0 & & & \\
\hline Mbita & 7 & 7.4 & 10 & 8.6 & 17 & 8.1 & & & \\
\hline Total & 94 & 100.0 & 116 & 100.0 & 210 & 100.0 & & & \\
\hline \multicolumn{10}{|l|}{ Job category } \\
\hline Managerial & 24 & 25.5 & 5 & 4.3 & 29 & 13.8 & & & \\
\hline Operations & 16 & 17.0 & 13 & 11.2 & 29 & 13.8 & & & \\
\hline Technical & 31 & 33.0 & 54 & 46.6 & 85 & 40.5 & 23.921 & 4 & $0.000 * * *$ \\
\hline Commercial & 16 & 17.0 & 27 & 23.3 & 43 & 20.5 & & & \\
\hline Finance & 7 & 7.4 & 17 & 14.7 & 24 & 11.4 & & & \\
\hline Total & 94 & 100.0 & 116 & 100.0 & 210 & 100.0 & & & \\
\hline \multicolumn{10}{|l|}{ Gender } \\
\hline Male & 76 & 80.9 & 93 & 80.2 & 169 & 80.5 & & & \\
\hline Female & 18 & 19.1 & 23 & 19.8 & 41 & 19.5 & 0.051 & 1 & 0.902 \\
\hline Total & 94 & 100.0 & 116 & 100.0 & 210 & 100.0 & & & \\
\hline $\begin{array}{l}\text { Highest } \\
\text { qualification }\end{array}$ & & & & & & & & & \\
\hline Certificate & 47 & 50.0 & 57 & 49.1 & 104 & 49.5 & & & \\
\hline Diploma & 39 & 41.5 & 53 & 45.7 & 92 & 43.8 & 1.885 & 3 & 0.597 \\
\hline Bachelors degree & 7 & 7.4 & 6 & 5.2 & 13 & 6.2 & & & \\
\hline Masters degree & 1 & 1.1 & 0 & 0.0 & 1 & 0.5 & & & \\
\hline Total & 94 & 100.0 & 116 & 100.0 & 210 & 100.0 & & & \\
\hline
\end{tabular}

Regarding job categories, $85(40.5 \%)$ respondents indicated various job titles that were lumped together as technical positions, $43(20.5 \%)$ stated job titles that fell under the commercial category, 29 (13.8\%) held managerial positions, another 29 (13.8\%) were in operations, while $24(11.4 \%)$ served in the finance department. Among those who felt that the utility's performance in defraying O\&M costs was GOOD (94), 31 (33.0\%) were in the technical job category, while $24(25.5 \%)$ held managerial positions. Among the 116 respondents who rated the utility's performance as POOR, again 54 (46.6\%) belonged to the technical category, while $27(23.3 \%)$ indicated titles that affiliated to commercial job category. Based on this, the analysis obtained a computed $\chi^{2}$ value of 23.921, with 4 degrees of freedom and a $\rho$-value of 0.000 , which suggests up to $99 \%$ chance that the utility's performance in defraying O\&M costs significantly associated with respondents' job category. This implies that views regarding the utility's performance varied significantly among officers in the five job categories.

Respondents included 169 (80.5\%) men and 41 (19.5\%) women. Among those who described the utility's performance as GOOD (94), up to $76(80.9 \%)$ were men. In the group that felt the performance was POOR (116), men formed the majority at $93(80.2 \%)$. The analysis revealed lack of a significant association between the utility's performance in defraying O\&M costs and respondents' gender $\left(\chi^{2}=0.051, \mathrm{df}=1 \& \rho\right.$-value $\left.=0.902\right)$, which implies that there was no significant variation in views expressed by male and female water officers regarding the utility's performance in defraying O\&M costs.

Respondents had attained various levels of professional qualifications, with up to 104 (49.5\%) holding certificates, $92(43.8 \%)$ having diplomas and 13 (6.2\%) indicating bachelors degree qualifications. Among those who rated the utility's performance as GOOD (94), 47 (50.0\%) held certificate level qualifications and 39 (41.5\%) stated diploma qualifications. Contrastingly, among those described performance as POOR (116), 57 (49.1\%) held certificate qualifications, while 53 (45.7\%) had diploma level qualifications. The analysis obtained a computed $\chi^{2}$ value of 1.885 , with 3 degrees of freedom and a $\rho$-value of 0.597 , which suggests lack of a significant association between the utility's performance in defraying O\&M costs and respondents' highest professional qualifications. This implies that respondents' views regarding the utility's performance were fairly homogenous, regardless of level of professional qualifications. 


\subsection{Bivariate Analysis of Financial Management Practices and the Utility's Financial Sustainability}

By subjecting water services to market forces of demand and supply, water sector reforms entrenched the aspect of commercialization, whose purpose was to orient water utilities towards cost recovery, efficiency and financial sustainability. Sound financial management practices are important antecedents to achieving the purpose of commercialization. This study examined five financial management practices that were identified through a review of policy and empirical literature, including compliance of procurement activities to relevant legislations, effectiveness of internal audit in enforcing expenditure policies, effectiveness of external audit in improving financial management practices, relevance of activities on which water revenues are spent, as well as conformance of expenditure to approved budgets. The stated aspects were used to formulate hypothetical test statements, against which respondents were required to indicate their honest views on a five-point measurement scale, which was calibrated as 'strongly agree', 'agree', 'undecided', 'disagree' and 'strongly disagree'.

In view of the above, respondents were requested to indicate their views regarding the hypothetical test item stating that 'expenditures are always within approved budgets'. The results in Table 3 show that of the 210 respondents, $88(41.9 \%)$ disagreed with the statement, while $18(8.6 \%)$ disagreed strongly. On the other side of the scale, $65(31.0 \%)$ respondents agreed with it, while $23(11.0 \%)$ agreed strongly. Cumulatively, up to 106 (50.5\%) respondents failed to endorse the statement, which implies that the utility's expenditures were not always within approved budgets; while $88(41.9 \%)$ endorsed it. In relation to the utility's performance in defraying O\&M costs, the results show that of the 94 respondents who rated the utility's performance as GOOD, 43 (45.7\%) agreed with test statement, while 20 (21.3) disagreed. Among the 116 respondents who described the utility's performance as POOR, up to $68(58.6 \%)$ disagreed with the statement, while $22(19.0 \%)$ indicated agreement. Based on this, the analysis obtained a computed $\chi^{2}$ value of 15.545 , with 4 degrees of freedom and a $\rho$-value of 0.004 , which suggests up to $99 \%$ chance that the utility's performance in defraying O\&M costs significantly associated with how often its expenditure conformed to approved budgets. The results imply that containing the utility's expenditures with approved budgets is a challenge, at least according to one-half of the respondents, which was likely to influence achievement of financial sustainability.

Table 3. Cross-tabulation of financial management practices and financial sustainability of the utility

\begin{tabular}{|c|c|c|c|c|c|c|c|c|c|}
\hline \multirow{3}{*}{ Financial management practices } & \multicolumn{6}{|c|}{ The utility's performance in defraying $O \& M$ costs } & \multirow{2}{*}{\multicolumn{3}{|c|}{$\begin{array}{l}\text { Summary of Chi Square } \\
\text { Results }\end{array}$}} \\
\hline & \multicolumn{2}{|c|}{ GOOD } & \multicolumn{2}{|l|}{ POOR } & \multicolumn{2}{|c|}{ TOTAL } & & & \\
\hline & Count & Percent & Count & Percent & Count & Percent & $\chi^{2}$ & $d f$ & $\rho$-value \\
\hline \multirow{2}{*}{\multicolumn{10}{|c|}{$\begin{array}{l}\text { Expenditures are always within approved } \\
\text { budgets }\end{array}$}} \\
\hline & & & & & & & & & \\
\hline Agree strongly & 16 & 17.0 & 7 & 6.0 & 23 & 11.0 & & & \\
\hline Agree & 43 & 45.7 & 22 & 19.0 & 65 & 31.0 & & & \\
\hline Undecided & 7 & 7.4 & 9 & 7.8 & 16 & 7.6 & 15.545 & 4 & $0.004 * * *$ \\
\hline Disagree & 20 & 21.3 & 68 & 58.6 & 88 & 41.9 & & & \\
\hline Disagree strongly & 8 & 8.5 & 10 & 8.6 & 18 & 8.6 & & & \\
\hline Total & 94 & 100.0 & 116 & 100.0 & 210 & 100.0 & & & \\
\hline \multicolumn{10}{|c|}{ Procurement of goods, services and works } \\
\hline \multicolumn{10}{|l|}{ is done in accordance with legislations } \\
\hline Agree strongly & 27 & 28.7 & 12 & 10.3 & 39 & 18.6 & & & \\
\hline Agree & 26 & 27.7 & 17 & 14.7 & 43 & 20.5 & & & \\
\hline Undecided & 2 & 2.1 & 3 & 2.6 & 5 & 2.4 & 35.040 & 4 & $0.000 * * *$ \\
\hline Disagree & 30 & 31.9 & 70 & 60.3 & 100 & 47.6 & & & \\
\hline Disagree strongly & 9 & 9.6 & 14 & 12.1 & 23 & 11.0 & & & \\
\hline Total & 94 & 100.0 & 116 & 100.0 & 210 & 100.0 & & & \\
\hline \multicolumn{10}{|c|}{$\begin{array}{l}\text { Internal audit is effective in enforcing } \\
\text { expenditure policies }\end{array}$} \\
\hline Agree strongly & 12 & 12.8 & 7 & 6.0 & 19 & 9.0 & & & \\
\hline Agree & 24 & 25.5 & 68 & 58.6 & 92 & 43.8 & & & \\
\hline Undecided & 7 & 7.4 & 5 & 4.3 & 12 & 5.7 & 28.024 & 4 & $0.000 * * *$ \\
\hline Disagree & 47 & 50.0 & 27 & 23.3 & 74 & 35.2 & & & \\
\hline Disagree strongly & 4 & 4.3 & 9 & 7.8 & 13 & 6.2 & & & \\
\hline Total & 94 & 100.0 & 116 & 100.0 & 210 & 100.0 & & & \\
\hline
\end{tabular}




\begin{tabular}{|c|c|c|c|c|c|c|c|c|c|}
\hline \multicolumn{10}{|c|}{$\begin{array}{l}\text { External audit is effective in improving } \\
\text { financial management practices }\end{array}$} \\
\hline Agree strongly & 16 & 17.0 & 6 & 5.2 & 22 & 10.5 & & & \\
\hline Agree & 39 & 41.5 & 32 & 27.6 & 71 & 33.8 & & & \\
\hline Undecided & 3 & 3.2 & 5 & 4.3 & 8 & 3.8 & 16.301 & 4 & $0.003 * * *$ \\
\hline Disagree & 25 & 26.6 & 48 & 41.4 & 73 & 34.8 & & & \\
\hline Disagree strongly & 11 & 11.7 & 25 & 21.6 & 36 & 17.1 & & & \\
\hline Total & 94 & 100.0 & 116 & 100.0 & 210 & 100.0 & & & \\
\hline \multicolumn{10}{|c|}{$\begin{array}{l}\text { Revenues are always spent on activities } \\
\text { relevant to sustainable delivery of quality }\end{array}$} \\
\hline Agree strongly & 13 & 13.8 & 6 & 5.2 & 19 & 9.0 & & & \\
\hline Agree & 35 & 37.2 & 30 & 25.9 & 65 & 31.0 & & & \\
\hline Undecided & 6 & 6.4 & 11 & 9.5 & 17 & 8.1 & 22.886 & 4 & $0.000 * * *$ \\
\hline Disagree & 27 & 28.7 & 60 & 51.7 & 87 & 41.4 & & & \\
\hline Disagree strongly & 13 & 13.8 & 9 & 7.8 & 22 & 10.5 & & & \\
\hline Total & 94 & 100.0 & 116 & 100.0 & 210 & 100.0 & & & \\
\hline
\end{tabular}

Note. $* * *, * * *$ show significance at $\rho<0.1, \rho<0.05$ and $\rho<0.01$ error margins, respectively.

Respondents were also requested to indicate their views regarding the test item, stating that 'procurement of goods, services and works is done in accordance with legislations'. The results in Table 3 show that of the 210 respondents, $100(47.6 \%)$ disagreed with the test statement, while $23(11.0 \%)$ disagreed strongly. Those who agreed were $43(20.5 \%)$, while those who agreed strongly were $39(18.6 \%)$. Cumulative results show that up to $123(58.6 \%)$ respondents negated the statement, which implies that procurement activities were not always done in accordance with legislations. However, $82(39.0 \%)$ affirmed the statement. In relation to the utility's performance in defraying O\&M costs, among those who described the utility's performance as GOOD (94), 30 (31.9\%) disagreed with the statement, while $26(27.7 \%)$ agreed. Contrastingly, among those who rated the utility's performance as POOR (116), up to 70 (60.3\%) disagreed with the statement, while $17(14.7 \%)$ agreed. The analysis revealed up to $99 \%$ chance that the utility's performance in defraying O\&M costs significantly associated with compliance of procurement activities to relevant legislations $\left(\chi^{2}=35.040\right.$, df $=4 \& \rho$-value $=$ 0.000). The results imply that compliance of procurement activities to relevant legislations was likely to improve the utility's financial sustainability.

The third aspect of financial management practices was about 'effectiveness of internal audit in enforcing expenditure policies'. In this regard, respondents were requested to indicate their views about the test item, stating that 'internal audit is effective in enforcing expenditure policies'. As indicated in Table 3, up to 74 (35.2\%) respondents disagreed with the statement, while $13(6.2 \%)$ disagreed strongly. Those who agreed with the statement were $92(43.8 \%)$, while those who agreed strongly were $19(9.0 \%)$. Cumulative results show that 111 $(52.9 \%)$ respondents endorsed the statement, which implies that internal audit was effective in enforcing expenditure policies; while $87(41.4 \%)$ negated the statement. Among those who felt that the utility's performance in defraying O\&M costs was GOOD (94), up to $47(50.0 \%)$ disagreed with the statement, while 24 (25.5\%) indicated agreement. Among those who described the utility's performance as POOR (116), 68 (58.6\%) agreed with the test statement, while $27(23.3 \%)$ disagreed. Following these results, the analysis obtained a computed $\chi^{2}$ value of 28.024 , with 4 degrees of freedom and a $\rho$-value of 0.000 , which suggests up to $99 \%$ chance that relationship between the utility's performance in defraying O\&M costs and effectiveness of internal audit in enforcing expenditure policies was statistically significant. The results imply that effectiveness of the internal audit to enforce expenditure policies was crucial in influencing the utility's financial sustainability.

The study also examined views regarding 'effectiveness of external audit in improving financial management practices'. In this regard, respondents were requested to indicate their views about the test item stating that 'external audit is effective improving the utility's financial management practices'. The results which are presented in Table 3 show that of the 210 respondents, 73 (34.8\%) disagreed with the statement, while $36(17.1 \%)$ disagreed strongly. On the other side of the scale, $71(33.8 \%)$ respondents agreed with the statement, while 22 $(10.5 \%)$ agreed strongly. Cumulatively, up to 109 (51.9\%) respondents negated the statement, which implies that external audit was not effective in improving financial management practices; while $93(44.3 \%)$ affirmed the statement. In relation to the utility's performance in defraying O\&M costs, among those who rated the performance as GOOD (94), up to 39 (41.5\%) agreed with the test statement, while 25 (26.6\%) disagreed. 
Contrastingly, of the 116 respondents who felt that the performance was POOR, 48 (41.4\%) disagreed with the test statement, while $32(27.6 \%)$ indicated agreement. The analysis revealed up to $99 \%$ chance that the relationship between the utility's performance in defraying O\&M costs and effectiveness of external audit in improving financial management practices, was statistically significant $\left(\chi^{2}=16.301, \mathrm{df}=4 \& \rho\right.$-value $\left.=0.003\right)$. The results imply that external audit was a crucial factor determining the utility's financial management practices.

Respondents were requested to indicate their views about the test item, stating that 'revenues are always spent on activities relevant to sustainable delivery of quality water services'. The results in Table 3 show that of the 210 respondents, 87 (41.4\%) disagreed with the statement, while $22(10.5 \%)$ disagreed strongly. Those who agreed with the statement were $65(31.0 \%)$, while $19(9.0 \%)$ indicated strong agreement. Cumulatively, up to 109 (51.9\%) respondents negated the test statement, the utility's revenues were not always spent on activities relevant to sustainable delivery of quality water services, while 84 (40.0\%), upheld the statement. Among those who felt that the utility's performance was GOOD (94), up to 35 (37.2\%) agreed with the test statement, while $27(28.7 \%)$ disagreed with it; while among those who described the utility's performance as POOR (116), up to $60(51.7 \%)$ disagreed with the test statement, while $30(25.9 \%)$ agreed. Based on this, the analysis obtained a computed $\chi^{2}$ value of 22.886, with 4 degrees of freedom and a $\rho$-value of 0.000 , which suggests up to $99 \%$ chance that the utility's performance in defraying O\&M costs significantly associated with relevance of activities on which water revenues were spent. The results imply that water revenues should not be spent in activities that are outside the purview of the utility's purpose. Minimizing expenditure in activities that are irrelevant to the utility's purpose prevents loss of resources that would be used to defray O\&M costs and to enhance financial sustainability.

\subsection{Relative Importance of Financial Management Practices and the Utility's Financial Sustainability}

Bivariate results presented in the foregoing sub-section revealed that the utility's performance in defraying O\&M costs significantly associated with all the five financial management practices examined by the study, including conformance of expenditure to approved budgets, which for the purpose of further analysis using the Relative Importance Index (RII) technique, was coded as ExBudgets; compliance of procurement activities to relevant legislations (PrLegislations), effectiveness of internal audit in enforcing expenditure policies (InAudit), effectiveness of external audit in improving financial management practices (ExAudit), as well as relevance of activities on which water revenues are spent (ReActivities). Table 4 presents the results of RII analysis, which include an inter-item correlation matrix, correlation co-efficients $(\beta)$, general dominance weights and relative weights. The latter indicates the importance of each financial management practice in relation to degree of variation in the utility's performance.

Table 4. Relative importance of financial management practices and the utility's performance

\begin{tabular}{|c|c|c|c|c|c|c|c|c|}
\hline \multicolumn{6}{|c|}{ INTER-ITEM CORRELATION MATRIX } & \multicolumn{3}{|c|}{ RELATIVE IMPORTANCE } \\
\hline $\begin{array}{l}\text { Financial management } \\
\text { practices }\end{array}$ & ExBudgets & PrLegislations & InAudit & ExAudit & ReActivities & $\beta$ & $\begin{array}{l}\text { General dominance } \\
\text { weights }\end{array}$ & $\begin{array}{l}\text { Relative } \\
\text { weights }\end{array}$ \\
\hline ExBudgets & 1.037 & 0.533 & 0.350 & 0.677 & 0.564 & 0.460 & 0.740 & 0.726 \\
\hline PrLegislations & 0.533 & 1.037 & 0.507 & 0.386 & 0.559 & 0.628 & 0.842 & 0.838 \\
\hline InAudit & 0.350 & 0.507 & 1.037 & 0.308 & 0.440 & 0.600 & 0.833 & 0.825 \\
\hline ExAudit & 0.677 & 0.386 & 0.308 & 1.037 & 0.584 & 0.478 & 0.758 & 0.749 \\
\hline ReActivities & 0.564 & 0.559 & 0.440 & 0.584 & 1.037 & 0.586 & 0.826 & 0.812 \\
\hline
\end{tabular}

The results in Table 4 show that compliance of procurement activities to relevant legislations (PrLegislations) was the most important financial management practice in relation to the degree of variation in the utility's performance, with a relative weight of 0.838 . Bivariate results presented in the previous sub-section indicated that up to $123(58.6 \%)$ respondents felt that procurement activities at the utility were not done in accordance with relevant legislations, which suggests that commercialization of water services had not influenced adherence to procurement laws and policies at the utility. In this regard, key informants and FGD participants indicated that procurement activities in the utility were characterized by a number of irregularities, including conflict of interest, which manifested through award of tenders to bidders associated with some officers and/or board members; and inflation of quotations, which distended procurement expenditure, and in some occasions, caused budget overruns. Participants also cited a few occasions, when the management precipitated the need for emergency procurement of goods and services without going through necessary procurement procedures, by 
failing to develop procurement plans in time. Emergency procurements were also caused by delayed disbursement of funds by the national government, which affected implementation of procurement plans.

The effectiveness of internal audit in enforcing expenditure policies (InAudit) was second in the order of relative importance, with a relative weight of 0.825 . Bivariate results showed that slightly more than one-half, 111 $(52.9 \%)$, of the respondents said the internal audit was effective in enforcing expenditure policies; however, up to $87(41.4 \%)$ respondents expressed contrary views, which suggests that internal audit experienced capacity challenges. Key informants confirmed this by identifying challenges such as inadequate staffing, which constrained detailed attention to enforce expenditure policies. Participants also mentioned lack of opportunities for internal audit staff development, which limited their capacity to comprehend the strategic direction, expectations of stakeholders, and financial risks facing the utility. As a result, internal audit staff lacked capacity to detect, question and mitigate irregular expenditures by the management. Some participants noted that lack of opportunities for professional development made internal audit staff easily compromised to overlook or cover-up irregular expenditures. Inadequate enforcement of expenditure policies contributed to loss of financial resources, which in turn, undermined achievement of financial sustainability.

The third aspect in the order of relative importance was the relevance of activities on which revenues are spent (ReActivities), with a relative weight of 0.812. Bivariate results indicated that $109(51.9 \%)$ respondents believed that the utility's water revenues were not always spent on activities that are relevant to sustainable delivery of quality water services. In this regard, KII and FGD participants cited a few activities which they perceived to be irrelevant, but were financed using water revenues, including foreign trips by senior management officers, too many stakeholder workshops and frequent engagement of consultants for activities that could be undertaken by water officers themselves. Participants noted that expenditure of water revenues in such activities demonstrated that the management lacked commitment to the utility's strategic focus; and that internal structures lacked capacity to control unnecessary expenditure. Participants further linked expenditure in such activities to political interference and ineffectiveness of external audit to improve financial management practices. Unnecessary expenditure of water revenues on irrelevant activities usurped resources meant for defraying O\&M costs, which prevented the utility from achieving financial sustainability.

The effectiveness of external audit in improving financial management practices (ExAudit) was fourth in the order of relative importance, with a relative weight of 0.749. About one-half of the respondents, 109 (51.9\%), hinted that external audit was not effective in improving financial management practices. Even though the utility was audited annually by the government's auditor general, the process was constrained by challenges such as inconsistency and delays, which provided opportunity for some officers to move to other institutions through transfers, without being held to account for loss of financial resources. Some KII and FGD participants perceived external audit as a mere formality, with no mechanism for implementation, monitoring and evaluation of audit recommendations. This was illustrated by certain recommendations which were often repeated in annual audit reports. Non-implementation of audit recommendations suggests that external audit failed to propagate a culture of fiscal discipline in the utility.

The fifth aspect in the order of relative importance was conformance of expenditure to approved budgets (ExBudgets), with a relative weight of 0.726 . Notably, up to $106(50.5 \%)$ respondents indicated that expenditures were not always within approved budgets, implying that there were occasions when the utility experienced budget overruns. This was confirmed by KII and FGD participants who linked budget overruns to expenditure of water revenues on activities that were not directly relevant to delivery of water services. Budget overruns were also attributed delayed disbursement of funds by the national government and unprecedentedly high inflation rates, which caused the prices of construction and infrastructural materials to overshoot budgetary estimates. Participants further linked budget overruns to procurement irregularities such splitting tenders into smaller units for unilateral approval, induced emergency procurements, where goods and services were procured without following due procedures; as well as inflation of quotations. Budget overruns affected the utility by precipitating financial constraints, which undermined the utility's performance in defraying O\&M costs. The results amplify the need for appropriate measures to prevent unnecessary expenditures and procurement irregularities, in order to contain expenditures within approved budgets.

\subsection{Concordance of Views on Financial Management Practices and the Utility's Financial Sustainability}

The analysis determined the extent to which respondents' views regarding the influence of financial management practices on the utility's financial sustainability converged. In this regard, the analysis generated mean ranks for each financial management practice, based on the degree of variation in the utility's performance in defraying O\&M costs. In this regard, the results in Table 5 show that compliance of procurement activities to relevant 
legislations (PrLegislations), with a mean rank of 3.713, influenced the largest variation on the utility's performance. Ranking second was the effectiveness of internal audit in enforcing expenditure policies (InAudit), with a mean rank of 3.520. This was followed by relevance of activities on which water revenues were spent (ReActivities) with a mean rank of 3.341; effectiveness of external audit in improving financial management practices (ExAudit) with a mean rank of 3.047, as well as conformance of expenditure to approved budgets (ExBudgets) with a mean rank of 2.906.

Table 5. Concordance of views regarding financial management practices

\begin{tabular}{llll}
\hline Ranks & \multicolumn{3}{l}{ Test Statistics } \\
\hline Financial management practices & Mean Rank & $\mathrm{N}$ & 210 \\
ExBudgets & 2.906 & Kendall's W & 0.862 \\
PrLegislation & 3.713 & Chi-Square $\left(\chi^{2}\right)$ & 64.491 \\
InAudit & 3.520 & df & 4 \\
ExAudit & 3.047 & $\rho$-value & 0.000 \\
ReActivities & 3.341 & a. Kendall's Coefficient of Concordance \\
\hline
\end{tabular}

The analysis obtained a coefficient of concordance (Kendall's W) of 0.862 , which suggests a strong level of concordance or convergence of respondents' views regarding the influence of financial management practices on the utility's financial sustainability. The analysis also obtained a computed $\chi^{2}$ of 64.491 , with 4 degrees of freedom (df) and a significance value ( $\rho$-value) of 0.000 , which suggest up to $99 \%$ chance that respondents' views regarding the relationship between financial management practices and the utility's financial sustainability were concordant. The results suggest that all the financial management practices were significant influencers of the utility's financial sustainability. In view of this, appropriate response interventions aimed at improving compliance of procurement activities to relevant legislations, capacity of the internal audit department, expenditure of water revenues, effectiveness of external audit, as well as conformity of expenditures to approved budgets should make significant contributions to improvement of utility's financial sustainability.

\section{Summary, Conclusions and Implications}

The purpose of this study was to determine how commercialization, as an aspect of water sector reforms, influenced the financial sustainability of HOMAWASCO, in order to inform stakeholders, contribute to policy discourses and programming decisions, as well as stimulate relevant research to aid sector development in Kenya and other developing countries. The study fulfilled the purpose by examining views of water officers holding managerial, operations, technical, commercial and finance positions; water users and water scheme management committee members. More specifically, the study focused on determining bivariate relationship between financial management practices and the utility's financial sustainability, which was measured in terms of its performance in defraying O\&M costs. The study also focused on determining: the relative importance of financial management practices based on the degree of variation in the utility's financial sustainability; and the concordance of respondents' views regarding the influence of financial management practices on the utility's financial sustainability.

The analysis revealed significant statistical associations between the utility's financial sustainability and all the financial management practices, including conformance of expenditures to approved budgets $\left(\chi^{2}=15.545, \mathrm{df}=4\right.$ $\& \rho$-value $=0.004) ;$ compliance of procurement activities to relevant legislations $\left(\chi^{2}=35.040, \mathrm{df}=4 \&\right.$ $\rho$-value $=0.000) ;$ effectiveness of internal audit in enforcing expenditure policies $\left(\chi^{2}=28.024, \mathrm{df}=4 \&\right.$ $\rho$-value $=0.000) ; \quad$ effectiveness of external audit in improving financial management practices $\left(\chi^{2}=16.301, \mathrm{df}\right.$ $=4 \& \rho$-value $=0.003)$ and relevance of activities on which water revenues were spent $\left(\chi^{2}=22.886, \mathrm{df}=4 \&\right.$ $\rho$-value $=0.000$ ). Regarding relative importance index, compliance of procurement activities to relevant legislations was the most the important aspect influencing the utility's financial sustainability, with a relative weight of 0.838 . The second aspect in the order of relative importance was the effectiveness of internal audit in enforcing expenditure policies (relative weight $=0.825$ ). This was followed by relevance of activities on which water revenues were spent (relative weight $=0.812$ ); effectiveness of external audit in improving financial management practices (relative weight $=0.749$ ); and conformance of expenditure to approved budgets (relative weight $=0.726$ ). The analysis obtained a strong and significant concordance of respondents' views regarding the relationship between financial management practices and the utility's financial sustainability (Kendall's $\mathrm{W}=$ $0.862, \chi^{2}=64.491, \mathrm{df}=4 \& \rho$-value $=0.000$ ); which implies interventions targeting the five financial management practices are likely to go a long way in improving the utility's financial sustainability. 
Organizations procure goods, services and works to facilitate their operations and fulfill their purpose in society. Well managed procurement activities are not only valuable to procuring organizations but also to sectoral and national development. Through procurement activities, organizations inject financial resources into the economy, which in turn, creates business opportunities for the private sector. However, poorly managed procurement systems and activities provide avenues through which organizations lose their financial resources. Scaling down to the context of this study, procurement can either improve or undermine financial sustainability of public water utilities, depending on the extent to which procurement legislations are embraced. In Kenya, public procurement is governed by the Public Procurement and Disposal Act of 2005, Public Procurement and Disposal Regulations, 2006 , as well as a number of sector and sub-sector specific manuals and guidelines. Nonetheless, having necessary legislative and policy frameworks is one thing; compliance to the provisions of such is another. In this study, participants cited irregularities such as inflation of quotations, which distended expenditure and caused budget overruns; conflict of interest, which manifested through awarding tenders to bidders associated and/or related to some senior management officers and board members; splitting tenders into two or more sub-tenders in order to sidestep threshold provisions and necessary procurement procedures; inducing emergency situations where procurement of goods and services were approved without going through due procedures. Ensuring that procurement activities are strictly guided by procurement laws and policies is important for preventing irregularities, minimizing loss of financial resources and enabling the utility to achieve financial sustainability. This calls for attention of the Public Procurement Oversight Authority (PPOA) and the Ethics and Anti-Corruption Commission (EACC) to sensitize all water officers and board members on procurement laws and policies; strengthen the utility's tender committee; improve monitoring and evaluation of procurement activities; and enforce adherence by prosecuting officers who fail to follow due procedures.

Internal audit enables organizations to manage their resources by detecting and preventing fraud, testing internal control policies and procedures, as well as monitoring and enforcing compliance with organizational expenditure policies, and government regulation. In this regard, internal audit provides organizational management with information on the effectiveness of risk management, control and governance processes, to support expenditure control decisions. However, effectiveness of internal audit department to fulfill its purpose depends on the prevalence of capacity challenges. In this study, participants noted that effectiveness of the utility's internal audit to enforce expenditure policies and prevent loss of financial resources was constrained by under-staffing, lack of training opportunities and lack of independence. In this regard, strengthening capacity of the internal audit department and enhancing its independence, are crucial antecedents for the utility to achieve financial sustainability. This may be realized by improving staffing levels and establishing/or strengthening staff development programs. The latter should focus on improving skills, knowledge and understanding of organizational risks, stakeholder expectations, cost optimization, credible service culture, as well as application of appropriate internal audit ICT tools.

By subjecting water services to market forces, the reforms amplified the importance of water revenues to the survival, efficiency and sustainability of public water utilities. In this regard, water revenues form the backbone of such utilities in a commercialized market. However, water revenues may not necessarily lead to financial sustainability in environments characterized by expenditure indiscipline. In other words, revenues only add value to financial sustainability where expenditure is streamlined, prioritized and focused on activities that are relevant to an organization's core mission. Such activities are ideally identified and defined in expenditure policies, which form part of financial budgets. Notably though, prioritizing expenditure and ensuring that revenues are spent on correct activities are two sides of a coin, as factors such as personal interests and political interference often influence expenditure decisions. The risk of expenditure indiscipline is particularly high in organizations where internal control structures are weak and external audit is conducted as a formality. In public water utilities, expenditure of revenues on irrelevant activities usurps resources that would be used to defray O\&M costs, which in turn, impedes achievement of financial sustainability. In this study, participants identified a number of activities that they considered irrelevant to the utility's mission, including foreign trips, consultancy services and stakeholder workshops. While recognizing that such activities are important to the utility, moderating their frequency is likely to yield greater value by preventing unnecessary expenditures. This calls for the water authorities, which in Kenya includes WRMAs and WSBs, to focus on strengthening internal expenditure control structures of public water utilities, through appropriate training to improve fiscal discipline, commitment to organizational strategic focus and implementation of external audit recommendations.

Regular audit of financial statements by external and independent agencies is vital for an organization's reputation, performance and sustainability. By examining the accuracy of financial statements, financial position and compliance with international accounting principles, external audit provides assurance to stakeholders that an 
organization's resources are managed properly and that, financial records are accurate and complete. External audit is particularly important when its able to identify inappropriate financial management practices that require corrective measures to enable organizations improve performance towards financial sustainability. In this regard, external audit processes are expected to recommend appropriate measures that should be taken by organizations to minimize wastage of resources or promote efficiency by tightening accounting practices. In Kenya, external audit of public institutions, organizations, programmes and projects is done by the Auditor General, as primarily mandated by the Public Audit Act, No. 34 of 2015 and Article 253 of the Constitution. Notably, the effectiveness of external audit optimizes when it's performed consistently, timely, objectively and inclusively; as well as when it delivers opinions that are acceptable to stakeholders and recommendations that are implementable. However, in this study, participants noted that effectiveness of external audit was constrained by delays, inconsistency and lack of mechanisms for ensuring recommendations are implemented. Improving external audit process by ensuring timeliness and consistency, as well as regular monitoring of how recommendations are implemented are crucial for the financial sustainability of public water utilities. This requires a collaborative intervention by water authorities and the public audit office.

Organizations prepare budgets to basically balance revenues and expenditures; and more specifically, to estimate revenues, predict revenue trends, prioritize allocation of resources as well as institute mechanisms for controlling expenditures. Such mechanisms are particularly important for preventing budget overruns, which often deplete contingency resources and heighten the risk of financial crunches. Even though budgeting is central to effective management of financial resources, budget overrun is a common challenge that prevents many public water utilities from achieving financial sustainability. In this study, participants cited budget overrun as one of the factors precipitating financial constraints, poor performance in defraying O\&M costs and inconsistent delivery of water services. Participants further linked budget overruns to over-expenditure of water revenues in activities that are not directly relevant to delivery of water services, procurement irregularities, weak internal control systems, as well as lack of a mechanism for monitoring and ensuring implementation of external audit recommendations. Addressing such underlying factors is likely to create a supportive environment for public water utilities to align their expenditures with approved budgets; thereby, avoid budget overruns and expedite financial sustainability. This may be achieved through sensitization and refresher training of utility management, internal audit departments and board members in order to enhance fiscal discipline, and skills in budgeting, budget implementation and expenditure control. This requires the intervention of water authorities. Equally important is the need to strengthen the procurement function through training and linkage with procurement and anti-corruption authorities, which in Kenya includes PPOA and EACC, in order to curb irregularities that increase the risk of budget overruns.

\section{References}

Adank, M., \&Tuffuor, B. (2013). Management Models for the Provision of Small Town and Peri-Urban Water Services in Ghana: TPP Synthesis Report. Accra: TPP Project/RCN Ghana.

Ashley, D., \& Orenstein, D. M. (2005). Sociological Theory: Classical Statements (6th ed.). Boston, MA, USA: Pearson Education.

Bowman, W. (2011). Financial Capacity and Sustainability of Ordinary Non-profits. Non-profit Management and Leadership, 22(1), 37-51.

Castro, V., Msuya, N., \& Makoye, C. (2009). Sustainable Community Management of Urban Water and Sanitation Schemes: A Training Manual. Nairobi: WASP.

Easterby-Smith, M., Thorpe, R., \& Lowe, A. (1991). The Philosophy of Research Design. Management Research: An Introduction. London: Sage Publications.

Fink, A. (1995). The Survey Kit: How to Sample in Surveys. Thousand Oaks, CA: Sage Publications.

Fragano, F. (2010). Management Models for Peri-Urban Community Water Projects in Paraguay. Itagua: Community Water Board.

Garson, G. D. (2009). Reliability Analysis. Journal of Modern Applied Statistical Methods, 6(1), 21-29.

Gia, L. H., \& Fugelsnes, T. (2010). Public-Private Partnerships for Small Piped Water Schemes. Nairobi: Water and Sanitation Program.

Government of Kenya. (2002). Water Act No. 8 of 2002. Nairobi: Government Printer.

Hughes, J. A., \& Sharrock, W. W. (1997). Philosophy of Social Research (3rd ed.). London: Longman

K'Akumu, O. A. (2006). Privatization Model for Water Enterprise in Kenya. Water Policy, 8(1), 539-557. 
K'Akumu, O. A., \& Appida, P. O. (2006). Privatization of urban water service provision: The Kenyan experiment. Water Policy, 8(4), 313-324.

León, P. (2001). Four Pillars of Financial Sustainability. Arlington, Virginia: The Nature Conservancy.

McPhail, A., Locussol, A. R., \& Perry, C. (2012). Achieving Financial Sustainability and Recovering Costs in Bank Financed Water Supply and Sanitation and Irrigation Projects. Washington, D.C.: The World Bank.

Mimrose, D. M., Gunawardena, E. R. N., \& Nayakakorala, H. B. (2011). Assessment of Sustainability of Community Water Supply Projects in Kandy District. Tropical Agricultural Research, 23(1), 51-60.

Nankunda, S. (2013). Internal Audit Function and Financial Perfromance of Public Sector Organizations: A Case of National Water and Sewerage Corporation - Mbarara Branch. A Research Report Submitted to the Faculty of Business and Development Studies, Bishop Stuart University.

Norman, G., \& Parkers, W. (2011). Business Model for Delegated Management Of Local Water Services Experience from Naivasha Kenya. Nairobi: WSUP.

Okeyo, J. O. (2011). Public Private Partnerships in the Privatization of Water Service Delivery in Kenya: Current Issues of Water Management. Retrieved from http://www.intechopen.com/books

Polit, D. E., \& Beck, C. T. (2006). Essentials of Nursing Research (6th ed.). Philadelphia: Lippincott Williams \& Wilkins.

Rampa, F. (2011). Analyzing Governance in the Water Sector in Kenya. Discussion Paper No. 124. Nairobi.

Sale, J. E. M., Lohfeld, L. H., \& Brazil, K. (2002). Revisiting the Quantitative-Qualitative Debate: Implications for Mixed Methods Research. Quality and Quantity, 36(1), 43-53.

Sanders, H., \& Fitts, J. (2011). Assessing the Sustainability of Rural Water Supply Programs: A Case Study of Pawaga, Tanzania. A Thesis submitted for the Award of Master of Arts Degree at Duke University.

Sheatsley, P. B. (1983). Questionnaire Construction and Item Writing. In P.H. Rossi, Wright, J.D. \& Anderson, A. B. (Eds.), Handbook of Survey Research. San Diego, CA: Academic Press, Inc.

UNICEF \& WHO. (2015). Joint Monitoring Program Report. New York: WHO.

United Nations. (2011). A Guidebook on Public-Private Partnership in Infrastructure. Bangkok, UNESCAP.

Wambua, S. (2004). Water Privatization in Kenya: Global Issue Papers, No.8. Berlin: Heinrich Foundation.

Water Resources Management Authority [WRMA]. (2013). Impact: A Performance Report of Kenya's Water Sector Reforms. Nairobi: WASRB.

Whittington, D., Davis, J., Prokopy, L., Komives, K., Thorsten, R., Lukacs, H., Bakalian, A., \& Wakeman, W. (2009). How Well Is the Demand-driven, Community Management Model for Rural Water Supply Systems Doing? Evidence from Bolivia, Peru and Ghana. Water Policy, 11, 696-718.

Williams, K. S. (2013). Non-Profit Financial Sustainability. A Thesis Submitted in Partial Fulfillment of the Requirements for the Degree of Master of Arts in Interdisciplinary Studies, Dalhousie University.

Wong, P. W. (2014). A Snapshot on Qualitative Research Methods. Educational Research and Reviews, 9(5), 130-140.

World Bank. (1997). Selecting an Option for Private Sector Participation. Washington DC: The International Bank for Reconstruction and Development/ the World Bank.

World Bank. (2008). Water Sector Reforms: Five Years On. New York: Water and Sanitation Program-Africa/World Bank.

World Bank. (2012). Public-Private Partnerships for Rural Water Services. Briefing Note No. 4. Washington, DC: World Bank.

\section{Copyrights}

Copyright for this article is retained by the author(s), with first publication rights granted to the journal.

This is an open-access article distributed under the terms and conditions of the Creative Commons Attribution license (http://creativecommons.org/licenses/by/4.0/). 